\title{
STUDY ON RHEOLOGICAL PROPERTIES OF EXTRA-HEAVY CRUDE OIL FROM FIELDS OF UKRAINE
}

\author{
Petro Topilnytskyy ${ }^{1} \otimes$, Viktoria Romanchuk $^{1}$, Tetiana Yarmola $^{1}$, Halyna Stebelska ${ }^{2}$
}

https://doi.org/10.23939/chcht14.03.412

\begin{abstract}
The rheological properties of oils from 3 wells of Yablunivske field (Poltava region, Ukraine) were investigated using a rotational viscometer. According to the dynamic viscosity and shear stress dependence on the shear velocity, the nature of the oil flow has been determined, which is of practical importance for evaluating the effectiveness of different modes of action on the rheological behavior of oils during their extraction and transportation.
\end{abstract}

Keywords: extra-heavy oil, oil transportation, oil rheological properties.

\section{Introduction}

To date, due to the steady depletion of light, lowviscosity oil reserves, the need for the developing of highviscosity oil and natural bitumen fields $[1,2]$ is increasingly important. As a rule, such fields are characterized by high concentration of metals and sulfur compounds, high values of density and viscosity, increased coking ability $[3,4]$ due to the high content of asphaltenes and resins. Taking into account the latter fact, such oils are extremely difficult to dehydrate [5]. The oils can also corrode the equipment, which in turn will result in the emergency shutdown of the entire refinery $[6,7]$.

Very often, high-viscosity crude oil fields are a complex multilayer system in which different "floors" have not only different filtration-capacity properties, but also different properties of the reservoir fluid [8]. The most important condition for the formation of extra-heavy crude oil is the loss of light fractions in the areas of tectonic disturbances, as well as hydrogeochemical and biochemical oxidation of oil in the zones of paleo- and modern hypergenesis. The reservoir waters in these zones oxidize oil by transferring chemical oxidizers and various reactive microorganisms resulting in increase of oil viscosity and decrease of oil mobility. Due to these

\footnotetext{
${ }^{1}$ Lviv Polytechnic National University

12, S. Bandery St., 79013 Lviv, Ukraine

${ }^{2}$ Geology Department, JSC Ukrgasvydobuvannia

petro.i.topilnytskyi@lpnu.ua

(C) Topilnytskyi P., Romanchuk V., Yarmola T., Stebelska H., 2020
}

factors, the secondary transformations of oil and its enrichment with heavy fractions occur.

All mentioned above leads to a higher production costs, increased cost of transportation by existing oil pipelines and difficulties in oil refining according to classical schemes $[9,10]$. While attempting to develop the field under natural mode, the high viscosity of such oil under reservoir conditions is the reason of low well yields, and sometimes even their absence. Since high-viscosity oil has a low content of gasoline and diesel fractions and a high content of heavy fuel oil with high pour point, such oil is not desirable to be processed under a traditional refinery scheme. However, it is a good raw material for the production of bitumen which has not to be modified further, compared with bitumen produced from conventional oil [11-14]. Usually the modification increases the bitumen cost and complicates the production scheme.

Oil rheological properties are important parameters allowing to substantiate and implement effective complex technologies for the oil recovery increase [15-17]. The peculiarity of extra-heavy oil rheological properties is variability of theirdynamic viscosity, which depends on the applied shear stress and shear rate . Oil flow is nonNewtonian fluid and is determined by its colloid-chemical state (composition of the dispersed phase and the dispersion medium), the nature of intermolecular interactions and structure formation [2]. The regularities of non-Newtonian fluids motion have a series of peculiarities.

For ordinary or Newtonian fluids, the relation between the shear stress $\tau$ and the shear rate $\frac{d w}{d n}$ is expressed as a straight line passing through the point of origin with a slope equal to viscosity value. The viscosity of non-Newtonian fluids at given temperatures and pressures does not remain constant, but varies depending on the shear rate, its duration, or the "previous history" of the fluid, as well as the design of the apparatus. Therefore, the dependence of $\tau$ on $\frac{d w}{d n}$ is nonlinear.

Non-Newtonian fluids can be divided into three groups. The first group includes viscous or stationary non- 
Newtonian fluids. For these liquids, the function $\frac{d w}{d n}=f(\tau)$ is independent on time. There are Bingam plastic fluids, pseudoplastic fluids and dilatant fluids depending on the function type.

The second group includes non-Newtonian fluids, in which the dependence between $\frac{d w}{d n}$ and $\tau$ changes over time. The structure of thixotropic fluids is destroyed and their fluidity increases with the increase in duration of the certain shear stress. But when the stress is removed, the fluid structure is gradually restored, and its flow is discontinued. The fluidity of rheopectant fluids decreases with the increase in shear stress duration.

The third group includes viscoelastic fluids, which flow under the stress $\tau$, but after removing the stress they partially restore their shape, like elastic solids.

According to experts' evaluation, the largest reserves of extra-heavy crude oil are located in Canada, Venezuela, and the Russian Federation. Many other countries in the world, such as China, the USA, Brazil, Iran, Mexico also have high-viscosity oil fields. Approximately $2 \%$ of the world's heavy oil reserves are concentrated in Ukraine. However, due to the complexity of oil sampling and insufficient production of such oil, there are practically no publications on their exploration [1]. A number of extra-heavy oil deposits have been found at the oil and gas condensate fields of the Dnieper-Donetsk Basin, for example the Yablunivske gas and condensate field, located in the Poltava region at a distance of $17 \mathrm{~km}$ from Lokhvitsa. Successful experience in the development of this field demonstrates the feasibility of "connecting" this additional source of hydrocarbons for the production of oil, gas and condensate [18].

The aim of this work is the investigation of rheological properties of oil from Yablunivske field to determine the efficient method of its extraction and suitability for transportation.

\section{Experimental}

To study the properties of extra-heavy oil from the Yablunivske field, the samples from three wells were taken:
Sample 1 - oil from well 88 with a density of $959 \mathrm{~kg} / \mathrm{m}^{3}$ at $323 \mathrm{~K}$;

Sample 2 - oil from well 94 with a density of $969 \mathrm{~kg} / \mathrm{m}^{3}$ at $323 \mathrm{~K}$;

Sample 3 - oil from well 337 with a density of $953 \mathrm{~kg} / \mathrm{m}^{3}$ at $323 \mathrm{~K}$.

The most important physico-chemical properties of oil from the Yablonivske field were investigated by us previously [8], and are presented in Table 1.

The degassed crude oil from the Yablonivske field with abnormally high viscosity belongs to heavy, highviscosity and sour oil.

The coking ability and pour point for all samples are extremely high, indicating a high content of asphaltresin hydrocarbons in oil. This will cause difficulties in the transportation of oil, especially at low temperatures, and will require additional measures to reduce the pour point. The chlorides and water content of the samples under study are also extremely high because the oil did not undergo desalination and dehydration, which are obligatory before refining. The kinematic viscosity of investigated oil at $323 \mathrm{~K}$ is quite high. The viscosity value is used to determine and calculate the following technological parameters: the mobility of oil in the reservoir during its production, the rate of filtration in the reservoir, the type of displacement agent, the capacity of the pump, the conditions of transportation through the pipeline, etc.

To improve oil recovery and to determine the method of oil viscosity reduction during transportation, their rheological properties were studied depending on temperature and shear rate. A modern high-precision rotational viscometer Rheomat-30 (Contraves AG, Switzerland) was used. Viscometer was equipped with a rotary-type adapter with coaxial cylinders. The CM409.484 measuring system consisted of a cylinder with $25 \mathrm{~mm}$ diameter and a chamber with $23.8 \mathrm{~mm}$ inner diameter and volume of $40 \mathrm{~cm}^{3}$. The range of shear rate was from 0 to $452 \mathrm{~s}^{-1}$; the temperature range was $293-343 \mathrm{~K}$. The required temperature was provided by a circulating thermostat UH-8 (MLW, Germany) equipped with a special flow cell. Demineralized water was used as a heat carrier.

Table 1

Physico-chemical properties of oil

\begin{tabular}{|c|c|c|c|}
\hline Property & Sample 1 & Sample 2 & Sample 3 \\
\hline Density at $293 \mathrm{~K}, \mathrm{~kg} / \mathrm{m}^{3}$ & 975 & 985 & 970 \\
\hline Kinematic viscosity at $323 \mathrm{~K}, \mathrm{~mm}^{2} / \mathrm{s}$ & 324 & 486 & 400 \\
\hline Coking ability, $\%$ & 10.1 & 10.6 & 7.1 \\
\hline Pour point, $\mathrm{K}$ & 290 & 317 & 282 \\
\hline Water content, \% & 5.0 & 25.0 & 5.5 \\
\hline Chlorides content, $\mathrm{mg} / \mathrm{dm}^{3}$ & 2890 & 5400 & 7351 \\
\hline Sulfuric-acid resins content, vol\% & 17.8 & 24.5 & 15.9 \\
\hline
\end{tabular}


The procedure was based on the determination of the dynamic (effective) viscosity of the fluids in the range of $0.1-4 \cdot 10^{5} \mathrm{~Pa} \cdot \mathrm{s}$. We registered the resistance moment of the inner cone of the measuring device with the test material at different strain-rate gradients, and calculated the shear stress and dynamic viscosity.

Dynamic viscosity $(\eta$, Pa.s $)$ was determined according to Eq. (1):

$$
\eta=\eta_{\text {rep }} \cdot \alpha
$$

where $\eta_{\text {rep }}$ is the viscosity, which corresponds to the position of the device switch at the shear stress for the corresponding measuring system, $\mathrm{Pa} \cdot \mathrm{s} ; \alpha$ is the device readings, $\%$.
The shear stress $(\tau, \mathrm{Pa})$ is determined according to Eq. (2):

$$
\tau=\eta \cdot D_{\text {rep }}
$$

where $D_{\text {rep }}$ is the shear rate, which corresponds to the position of the device switch at the shear stress for the corresponding measuring system, $\mathrm{s}^{-1}$.

\section{Results and Discussion}

To construct rheological flow curves in the $\tau-\eta-D$ coordinates, we used experimental results obtained for all three samples at $293 \mathrm{~K}$ (Tables 2-4) and at the temperatures of 303, 313, 323, 333 and $343 \mathrm{~K}$ (Figs. 1-6).

Table 2

\section{Dynamic viscosity of Sample 1 at 293 K}

\begin{tabular}{|c|c|c|c|c|}
\hline Shear rate $D_{\text {rep }}, \mathrm{s}^{-1}$ & $\begin{array}{c}\text { Viscosity, which corresponds to the position of } \\
\text { the device switch at the shear stress for the } \\
\text { corresponding measuring system } \eta_{\text {rep }}, \mathrm{Pa} \cdot \mathrm{s}\end{array}$ & $\begin{array}{c}\text { Device readings } \\
\alpha, \%\end{array}$ & $\begin{array}{c}\text { Dynamic viscosity } \\
\eta, \mathrm{Pa} \cdot \mathrm{s}\end{array}$ & $\begin{array}{c}\text { Shear stress } \\
\tau, \mathrm{Pa}\end{array}$ \\
\hline 3.32 & 0.337 & 0.5 & 0.1685 & 0.5594 \\
\hline 4.52 & 0.248 & 19 & 4.712 & 21.2982 \\
\hline 6.15 & 0.182 & 20.5 & 3.7310 & 22.9456 \\
\hline 8.35 & 0.134 & 29 & 3.8860 & 32.4481 \\
\hline 11.35 & 0.0987 & 36.5 & 3.6025 & 40.8883 \\
\hline 15.4 & 0.0727 & 46 & 3.3442 & 51.5006 \\
\hline 21.0 & 0.0533 & 58 & 3.0914 & 64.9194 \\
\hline 28.5 & 0.0393 & 73 & 2.8689 & 81.7636 \\
\hline 38.7 & 0.0289 & 92.5 & 2.6732 & 103.4528 \\
\hline 52.7 & 0.0213 & 108 & 2.3004 & 121.2310 \\
\hline 71.7 & 0.0156 & 145 & 2.2620 & 162.1854 \\
\hline 97.3 & 0.0115 & 195 & 2.2425 & 218.195 \\
\hline 132 & 0.00848 & 266 & 2.2557 & 297.750 \\
\hline 180 & 0.00622 & 354 & 2.2019 & 396.338 \\
\hline 245 & 0.00457 & 480 & 2.1936 & 537.432 \\
\hline 332 & 0.00337 & 635 & 2.1400 & 710.463 \\
\hline 452 & 0.00248 & 835 & 2.0708 & 936.002 \\
\hline
\end{tabular}

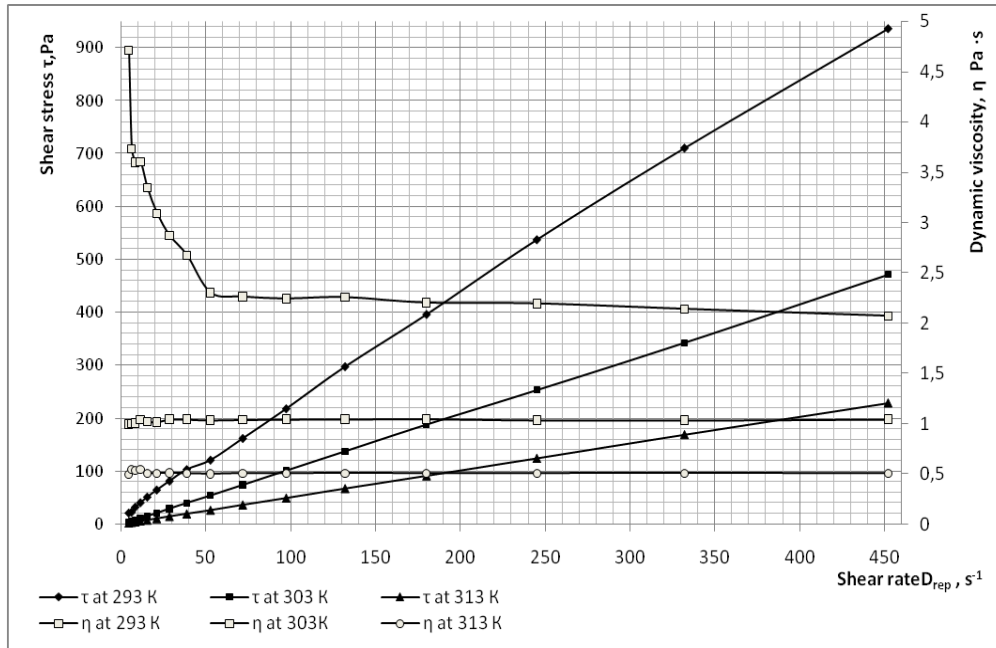

Fig. 1. Rheological properties of Sample 1 at 293, 303 and 313 K 


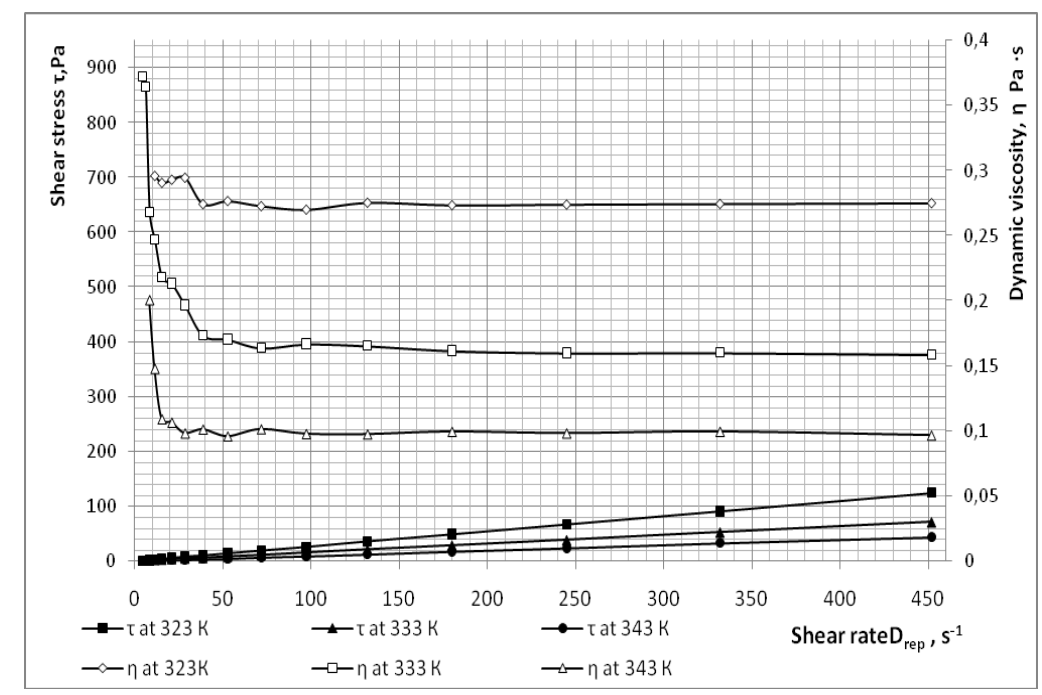

Fig. 2. Rheological properties of Sample 1 at 323, 333 and $343 \mathrm{~K}$

Table 3

Dynamic viscosity of Sample 2 at 293 K

\begin{tabular}{|c|c|c|c|c|}
\hline Shear rate $D_{\text {rep }}, \mathrm{s}^{-1}$ & $\begin{array}{l}\text { Viscosity, which corresponds to the position of } \\
\text { the device switch at the shear stress for the } \\
\text { corresponding measuring system } \eta_{\text {rep }}, \mathrm{Pa} \cdot \mathrm{s}\end{array}$ & $\begin{array}{c}\text { Device readings } \\
\qquad \alpha, \%\end{array}$ & $\begin{array}{c}\text { Dynamic viscosity } \\
\eta, \mathrm{Pa} \cdot \mathrm{s}\end{array}$ & $\begin{array}{c}\text { Shear stress } \\
\tau, \mathrm{Pa}\end{array}$ \\
\hline 0.0615 & 18.211 & 7.5 & 136.582 & 8.3998 \\
\hline 0.0835 & 13.413 & 10 & 134.130 & 11.1998 \\
\hline 0.1135 & 9.868 & 13 & 128.284 & 14.5602 \\
\hline 0.154 & 7.273 & 17.5 & 127.2775 & 19.6007 \\
\hline 0.210 & 5.333 & 22.5 & 119.992 & 25.198 \\
\hline 0.285 & 3.930 & 30 & 117.900 & 33.6015 \\
\hline 0.387 & 2.894 & 41 & 118.6540 & 45.9190 \\
\hline 0.527 & 2.125 & 52 & 110.500 & 58.2335 \\
\hline 0.717 & 1.562 & 74 & 115.588 & 82.8765 \\
\hline 0.973 & 1.151 & 98 & 112.798 & 102.752 \\
\hline 1.32 & 0.848 & 123 & 104.304 & 137.6812 \\
\hline 1.80 & 0.622 & 161 & 100.142 & 180.2556 \\
\hline 2.45 & 0.457 & 206 & 94.1420 & 230.6479 \\
\hline 3.32 & 0.337 & 264 & 88.9680 & 295.3737 \\
\hline 4.52 & 0.248 & 340 & 84.32 & 381.126 \\
\hline 6.15 & 0.182 & 430 & 78.26 & 481.299 \\
\hline 8.35 & 0.134 & 555 & 74.37 & 620.990 \\
\hline 11.35 & 0.0987 & 695 & 68.60 & 778.570 \\
\hline 15.4 & 0.0727 & 865 & 62.89 & 968.437 \\
\hline
\end{tabular}

Analysis of Sample 1 shows that at $293 \mathrm{~K}$ the oil viscosity decreases from 4.71 to $2.30 \mathrm{~Pa} \cdot \mathrm{s}$ with a slight change in shear rate from 4.52 to $52.7 \mathrm{~s}^{-1}$ (Table 2). Further increase in shear rate from 52.7 to $452 \mathrm{~s}^{-1}$ decreases the dynamic viscosity to $2.07 \mathrm{~Pa} \cdot \mathrm{s}$. Under the same conditions, the dependence of shear stress on the shear rate is nonlinear and the shear stress varies from 936 to $21.3 \mathrm{~Pa}$. Thus, at $293 \mathrm{~K}$ Sample 1 behaves as a non-Newtonian pseudoplastic fluid.
With the increase in temperature from 293 to $343 \mathrm{~K}$, it is another nature of the dynamic viscosity changes. Thus, when the shear rate is increased from 4.52 to $452 \mathrm{~s}^{-1}$, the dynamic viscosity of Sample 1 changes slightly: from 0.99 to $1.04 \mathrm{~Pa} \cdot \mathrm{s}$ at $303 \mathrm{~K}$, from 0.496 to $0.506 \mathrm{~Pa} \cdot \mathrm{s}$ at $313 \mathrm{~K}$, from 0.37 to $0.27 \mathrm{~Pa} \cdot \mathrm{s}$ at $323 \mathrm{~K}$, from 037 to $0.16 \mathrm{~Pa} \cdot \mathrm{s}$ at $333 \mathrm{~K}$ and from 0.20 to $0.10 \mathrm{~Pa} \cdot \mathrm{s}$ at $343 \mathrm{~K}$. The dependence of the shear stress on the shear rate is linear and at the shear rate of $452 \mathrm{~s}^{-1}$, in the temperature range of $303-343 \mathrm{~K}$ Sample 1 behaves already as a Newtonian fluid. 


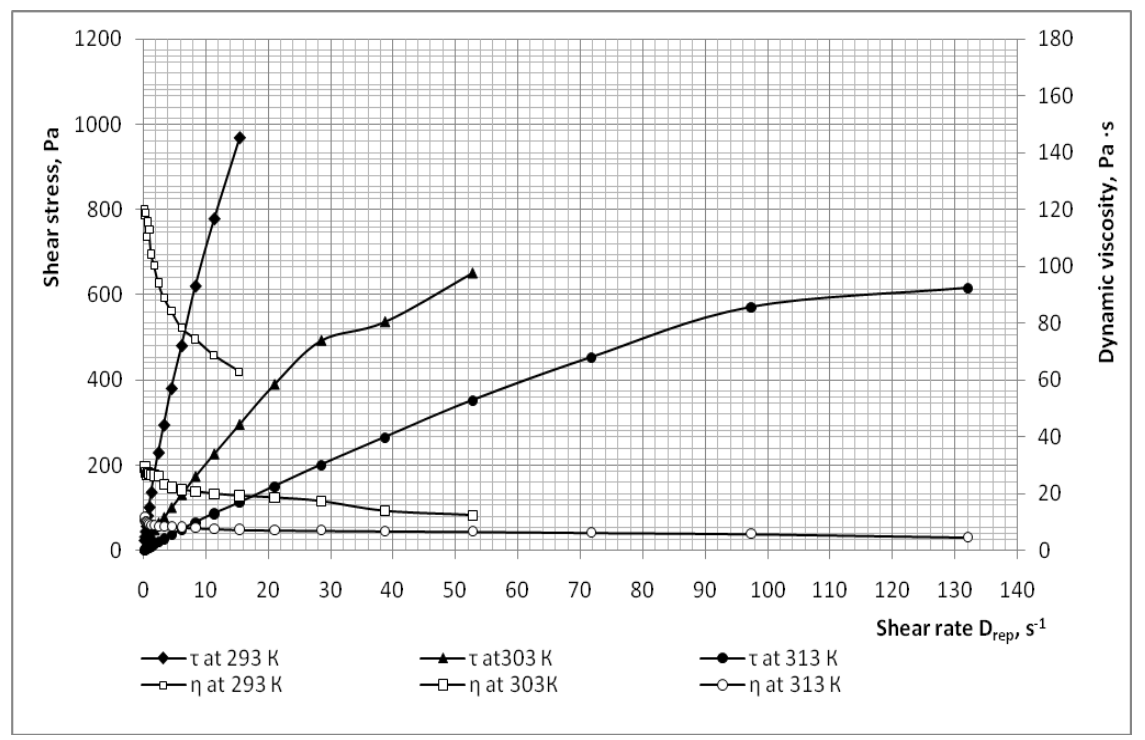

Fig. 3. Rheological properties of Sample 2 at 293, 303 and $313 \mathrm{~K}$

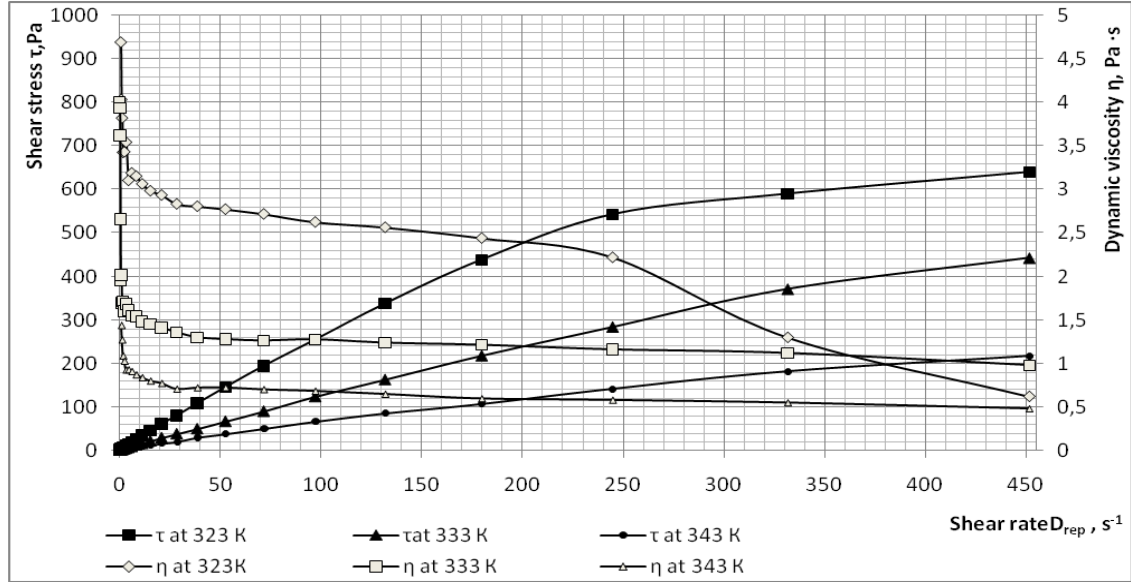

Fig. 4. Rheological properties of Sample 2 at 323, 333 and $343 \mathrm{~K}$

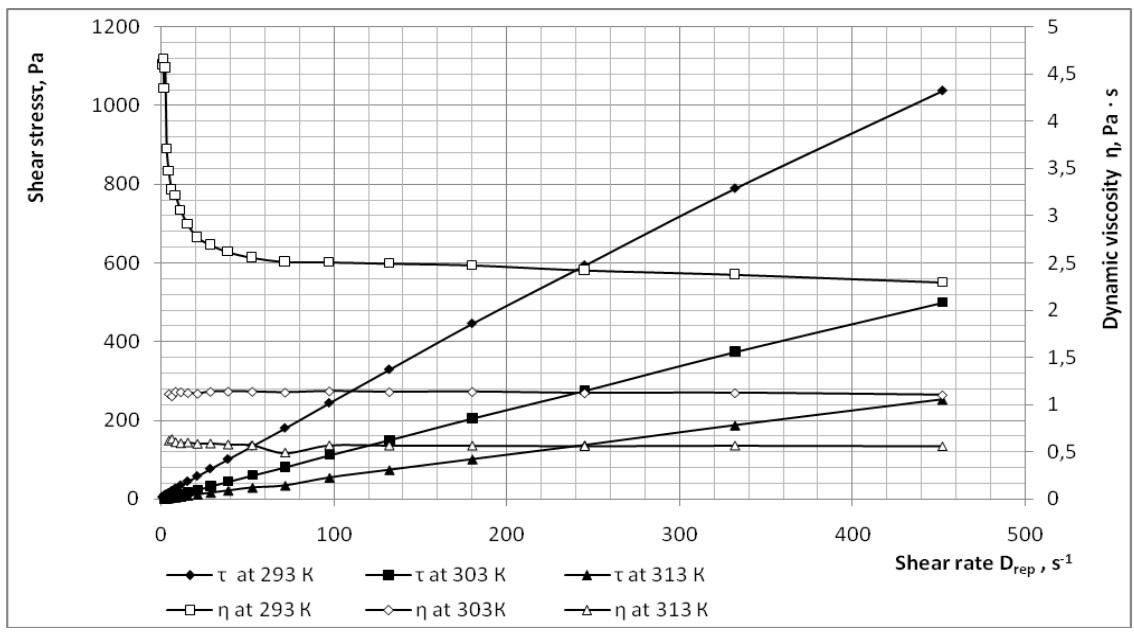

Fig. 5. Rheological properties of Sample 3 at 293, 303 and $313 \mathrm{~K}$ 


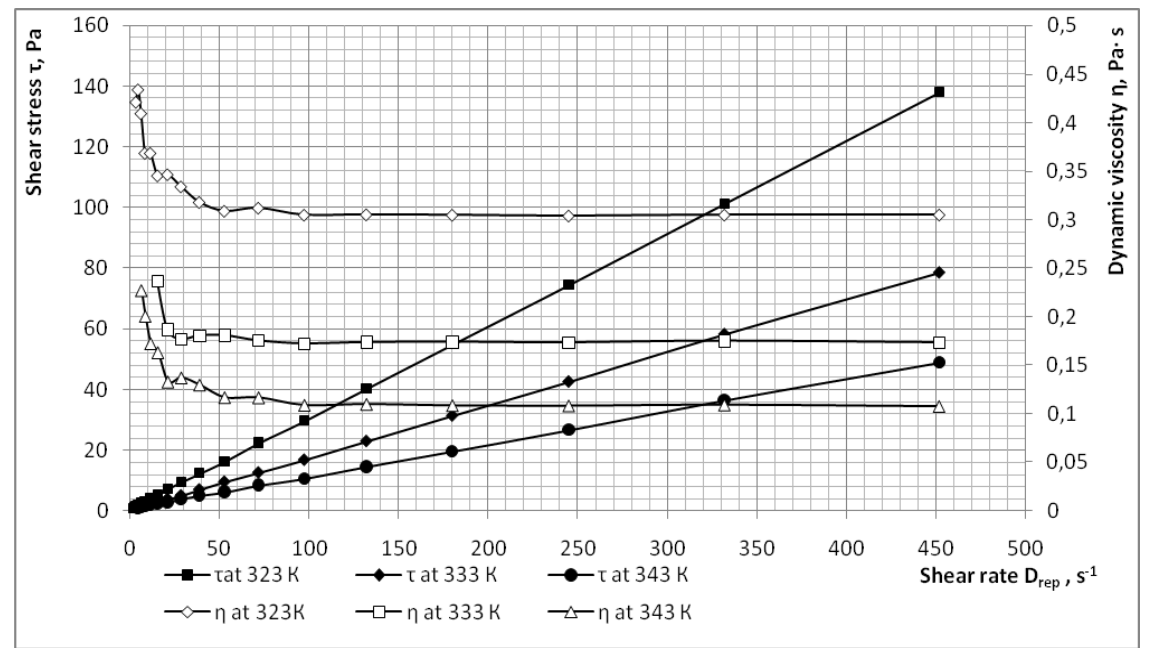

Fig. 6. Rheological properties of Sample 3 at 323, 333 and $343 \mathrm{~K}$

Table 4

Dynamic viscosity of Sample 3 at 293 K

\begin{tabular}{|c|c|c|c|c|}
\hline Shear rate $D_{r e p}, \mathrm{~s}^{-1}$ & $\begin{array}{l}\text { Viscosity, which corresponds to the position of } \\
\text { the device switch at the shear stress for the } \\
\text { corresponding measuring system } \eta_{\text {rep }}, \mathrm{Pa} \cdot \mathrm{s}\end{array}$ & $\begin{array}{c}\text { Device readings } \\
\qquad \alpha, \%\end{array}$ & $\begin{array}{c}\text { Dynamic viscosity } \\
\eta \eta, \mathrm{Pa} \cdot \mathrm{s}\end{array}$ & $\begin{array}{c}\text { Shear stress } \\
\tau, \mathrm{Pa}\end{array}$ \\
\hline 0.527 & 2.125 & 0.5 & 1.0625 & 0.5600 \\
\hline 0.717 & 1.562 & 2.5 & 3.905 & 2.7998 \\
\hline 0.973 & 1.151 & 4.0 & 4.604 & 4.4797 \\
\hline 1.32 & 0.848 & 5.5 & 4.664 & 6.1564 \\
\hline 1.80 & 0.622 & 7.0 & 4.354 & 7.8372 \\
\hline 2.45 & 0.457 & 10 & 4.570 & 11.1965 \\
\hline 3.32 & 0.337 & 11 & 3.707 & 12.3072 \\
\hline 4.52 & 0.248 & 14 & 3.472 & 15.693 \\
\hline 6.15 & 0.182 & 18 & 3.276 & 20.1474 \\
\hline 8.35 & 0.134 & 24 & 3.2160 & 26.8536 \\
\hline 11.35 & 0.0987 & 31 & 3.0597 & 34.7275 \\
\hline 15.4 & 0.0727 & 40 & 2.908 & 44.7832 \\
\hline 21.0 & 0.0533 & 52 & 2.7716 & 58.204 \\
\hline 28.5 & 0.0393 & 68.5 & 2.692 & 76.722 \\
\hline 38.7 & 0.0289 & 90.5 & 2.6154 & 101.2159 \\
\hline 52.7 & 0.0213 & 120 & 2.556 & 134.7012 \\
\hline 71.7 & 0.0156 & 161 & 2.5116 & 180.0817 \\
\hline 97.3 & 0.0115 & 218 & 2.507 & 243.931 \\
\hline 132 & 0.00848 & 294 & 2.4931 & 329.0892 \\
\hline 180 & 0.00622 & 398 & 2.4755 & 445.590 \\
\hline 245 & 0.00457 & 530 & 2.4221 & 593.4145 \\
\hline 332 & 0.00337 & 705 & 2.3758 & 788.7656 \\
\hline 452 & 0.00248 & 925 & 2.294 & 1036.89 \\
\hline
\end{tabular}

Sample 2 has a substantially higher value of dynamic viscosity. At the shear rate of $0.06 \mathrm{~s}^{-1}$ the dynamic viscosity is $136.58 \mathrm{~Pa} \cdot \mathrm{s}$. With the increase in shear rate to $4.52 \mathrm{~s}^{-1}$ the viscosity decreases to 62.89 $\mathrm{Pa} \cdot \mathrm{s}$. The shear stress with increasing shear rate increases sharply from 8.40 to $968.44 \mathrm{~Pa}$, i.e. by 115 times. The increase in temperature from 303 to $343 \mathrm{~K}$ decreases viscosity far less dramatically, but the values of shear stress at all temperatures are significant (651-217 Pa). At the values of shear rate higher than $21 \mathrm{~s}^{-1}$, the dynamic viscosity dependence is nonlinear, so it can be concluded that Sample 2 behaves as a nonNewtonian pseudoplastic fluid in the whole temperature range from 293 to $343 \mathrm{~K}$. 
For Sample 3 the dynamic viscosity is $4.60 \mathrm{~Pa} \cdot \mathrm{s}$ at the shear rate of $0.97 \mathrm{~s}^{-1}$, and even with its increase to $21 \mathrm{~s}^{-1}$, the viscosity decreases to $2.77 \mathrm{~Pa} \cdot \mathrm{s}$. Further increase in shear rate by 21.5 times decreases the dynamic viscosity to only $2.29 \mathrm{~Pa} \cdot \mathrm{s}$. In this case, the shear stress increased from 4.48 to $1036.89 \mathrm{~Pa}$, i.e. by 230 times. Unambiguously, Sample 3 at the temperature of $293 \mathrm{~K}$ refers to non-Newtonian pseudoplastic fluids.

When the temperature is increased by only $10 \mathrm{~K}$, the oil viscosity decreases by 3.4 times. However, with increasing temperature from 303 to $343 \mathrm{~K}$ and the shear rate from 0.97 to $452 \mathrm{~s}^{-1}$ the change in viscosity is negligible - only 10-30\%. The shear stress increases from 48.76 to $498.83 \mathrm{~Pa}$ with the decrease in temperature from 343 to $303 \mathrm{~K}$. The dependence of the shear stress on the shear rate is linear and at the value of $452 \mathrm{~s}^{-1}$ the Sample 3 behaves as a Newtonian fluid in the temperature range of 303-343 K.

Graphic example of the dynamic viscosity and shear stress dependence on the temperature is given in Figs. 7 and 8 (obtained on the data of Figs. 1-3 at the shear rate of $\left.4.52 \mathrm{~s}^{-1}\right)$.

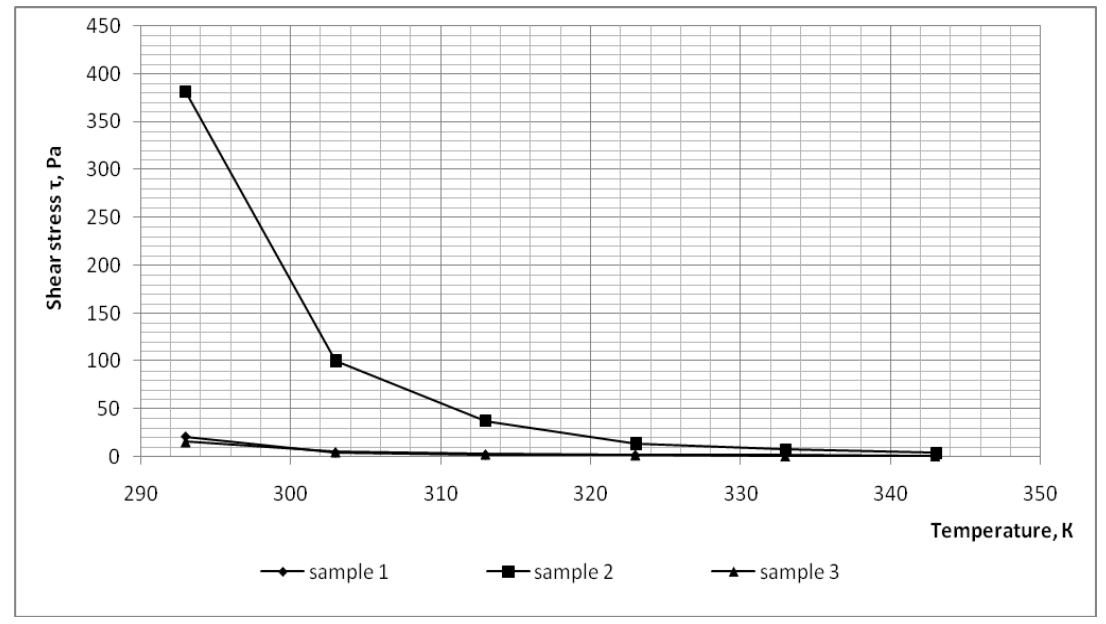

Fig. 7. Shear stress $v s$. temperature at the shear rate of $4.52 \mathrm{~s}^{-1}$

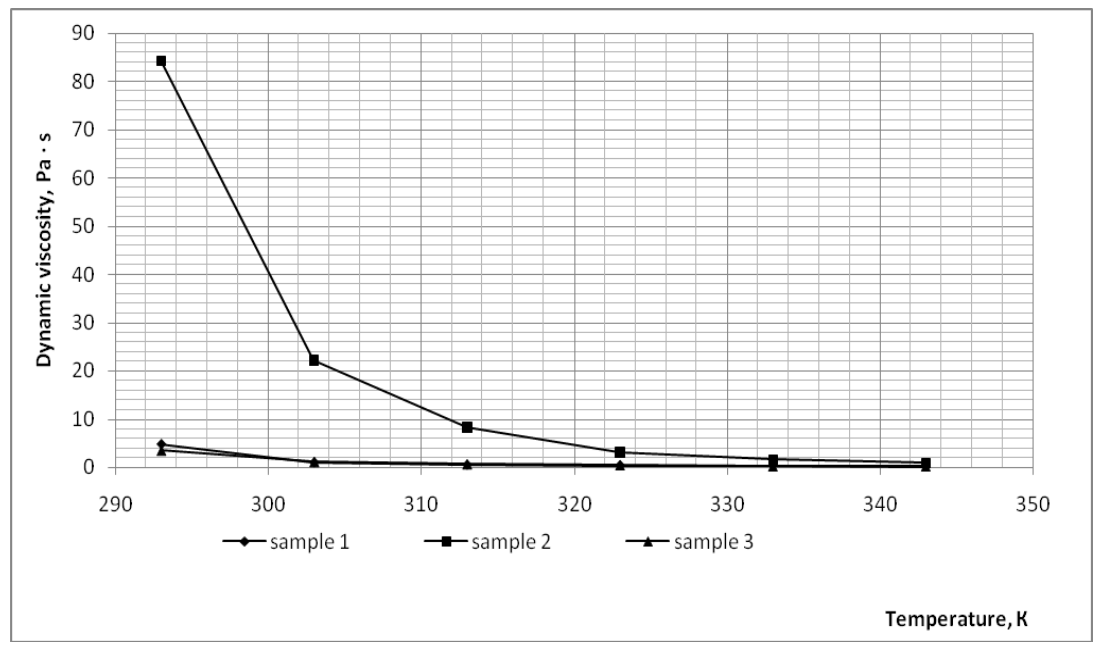

Fig. 8. Dynamic viscosity vs. temperature at the shear rate of $4.52 \mathrm{~s}^{-1}$

The shear stress of the Samples 1 and 3 linearly decreases with the increase in temperature from 293 to $343 \mathrm{~K}$. A sharp decrease is observed only in the region of 293-303 K (from 21.3 Pa for the Sample 1 and 15.7 Pa for the Sample 3 to $5.04 \mathrm{~Pa}$ ). Then the curve becomes linear, which confirms that under $303 \mathrm{~K}$ the Samples 1 and 3 behave as non-Newtonian fluids. With increasing temperature to $343 \mathrm{~K}$ the flow character becomes linear, and therefore the oils become Newtonian.

The shear stress and dynamic viscosity of Sample 2 are significantly higher than those of Samples 1 and 3 . The viscosity changes especially dramatically as the 
temperature increases from 293 to $303 \mathrm{~K}$; it decreases by more than 3.9 times. The same is observed for the shear stress which is changed by 3.8 times. Further increase in temperature results in the decrease in both shear stress and dynamic viscosity, but without sharp drop.

\section{Conclusions}

The rheological properties of extra-heavy crude oil from three wells of the Yablunivske field have been investigated. At the temperature of $293 \mathrm{~K}$ and within the shear rate range of $0.7-452 \mathrm{~s}^{-1}$ the shear stress of Samples 1 and 3 nonlinearly depends on the shear rate. The samples behave as non-Newtonian fluids but at the temperatures above $303 \mathrm{~K}$ they become Newtonian ones. Thus, for this type of oil the transfer with heating is advisable.

The dependence of shear stress on shear rate is nonlinear for sample 2 in the temperature range of 293$343 \mathrm{~K}$ at a shear rate higher than $21 \mathrm{~s}^{-1}$. Thus, it can be concluded that in the whole range of temperatures Sample 2 behaves as a non-Newtonian pseudoplastic fluid.

The investigated rheological properties are of practical importance for evaluating the effectiveness of different modes of action on the rheological behavior of crude oil during its extraction and transportation. When heating Samples 1 and 3 to the temperatures above $293 \mathrm{~K}$, their non-Newtonian properties are smoothed and the dependence of the dynamic viscosity on the shear rate decreases. Sample 2 requires more heating or other methods of reducing the viscosity (adding anti-viscosity modifiers or even depressants).

\section{References}

[1] Polishchuk Yu., Iashchenko I.: Neftegazovoe Delo, 2005, 1. [2] Pharmanzade A., Karpunin N., Khromykh L. et al.: Mezhdunar. Nauchno-Issled. Zh., 2016, 3, 116. https://doi.org/10.18454/IRJ.2016.45.050

[3] Roschin P., Zinoviev A., Struchkov I. et al.: Mezhdunar. Nauchno-Issled. Zh., 2015, 6, 120.

[4] Bratychak M., Gunka V.: Khimia Hafty i Gazu. Vyd-vo LP, Lviv 2017.

[5] Topilnytskyy P., Romanchuk V., Boichenko S., Golych Y.: Chem. Chem. Technol., 2014, 8, 211.

https://doi.org/10.23939/chcht08.02.211
[6] Romanchuk V., Topilnytskyy P.: Chem. Chem. Technol., 2010, 4, 231 .

[7] Gajek A., Zakroczymski T., Topilnytsky P., Romanchuk V.: Chem. Chem. Technol., 2012, 6, 209.

https://doi.org/10.23939/chcht06.02.209

[8] Topilnytskyy P., Paiuk S., Stebelska H. et al.: Chem. Chem. Technol., 2019, 13, 503. https://doi.org/10.23939/chcht13.04.503 [9] Hrynyshyn O., Al-Ameri M., Khlibyshyn Y.: East-Eur. J. Adv. Technol., 2013, 5/6, 27.

[10] Pylypiv L.: Naftogazova Galuz Ukrainy, 2016, 6, 29.

[11] Pyshyev S., Gunka V., Grytsenko Y., Bratychak M.: Chem. Chem. Technol., 2016, 10, 631.

https://doi.org/10.23939/chcht10.04si.631

[12] Demchuk Y., Sidun I., Gunka V. et al.: Chem. Chem. Technol., 2018, 12, 456. https://doi.org/10.23939/chcht12.04.456

[13] Pyshyev S., Gunka V., Grytsenko Y. et al.: Int. J. Pavement Res. Techn. Open, 2017, 10, 289.

https://doi.org/10.1016/j.ijprt.2017.05.001

[14] Al-Ameri M., Grynyshyn O., Khlibyshyn Y.: Chem. Chem. Technol., 2013, 7, 323. https://doi.org/10.23939/chcht07.03.323

[15] Safieva R.: Physicokhimia Hefti. Physico-khimicheskie Osnovy Technologii Pererabotki Nefti. Khimia, Moskva 1998. [16] Yaghi B., Al-Bemani A.: Energ. Sour., 2002, 24, 93. https://doi.org/10.1080/00908310252774417

[17] Henaut I., Barre L., Argillier J.-F. et al.: SPE Int. Symp. on Oilfield Chemistry, 13-16 February 2001, Houston, Texas. https://doi.org/10.2118/65020-MS

[18] https://dt.ua/ECONOMICS/potuzhniy_ vuglevodneviy_potentsial_nadr_ukrayini_osnova_priydeshnoyi_en ergetichnoyi_nezalezhnosti.html

Received: May 15, 2019/Revised: May 22, $2019 /$ Accepted: July 02, 2019

\section{ДОСЛІДЖЕННЯ РЕОЛОГІЧНИХ ВЛАСТИВОСТЕЙ ВАЖКИХ ВИСОКОВ'ЯЗКИХ НАФТ РОДОВИЩ УКРАЇНИ}

\begin{abstract}
Анотація. Досліджено реологічні властивості високов'язких нафт з 3-х свердловин Яблунівського родовища (Полтавська обл., Україна) за допомогою ротаційного віскозиметра. За характером кривих залежності динамічної в'язкості та напруження зсуву від швидкості зсуву встановлено характер течії даних нафт, що має практичне значення для оцінки ефективності різних способів дії на реологічну поведінку ичих нафт при їх видобутку та транспортуванні.
\end{abstract}

Ключові слова: важка нафта, транспортування нафти, реологічні властивості нафти. 